\title{
Characterisation of Physical, Spectral and Thermal Properties of Biofield treated Resorcinol
}

\author{
Mahendra Kumar Trivedi', Alice Branton ${ }^{1}$, Dahryn Trivedi', Gopal Nayak ${ }^{1}$, Ragini Singh ${ }^{2}$ and Snehasis Jana ${ }^{2 *}$ \\ ${ }^{1}$ Trivedi Global Inc., 10624 S Eastern Avenue Suite A-969, Henderson, NV 89052, USA \\ ${ }^{2}$ Trivedi Science Research Laboratory Pvt. Ltd., Hall-A, Chinar Mega Mall, Chinar Fortune City, Hoshangabad Rd., Bhopal, Madhya Pradesh, India
}

\begin{abstract}
Resorcinol is widely used in manufacturing of several drugs and pharmaceutical products that are mainly used for topical ailments. The main objective of this study is to use an alternative strategy i.e., biofield treatment to alter the physical, spectral and thermal properties of resorcinol. The resorcinol sample was divided in two groups, which served as control and treated group. The treated group was given biofield treatment and both groups i.e., control and treated were analysed using X-ray diffraction (XRD), Fourier transform-infrared (FT-IR) spectroscopy, UV-Visible (UVVis) spectroscopy, Differential scanning calorimetry (DSC) and Thermogravimetric analysis (TGA). The results showed a significant decrease in crystallite size of treated sample i.e., $104.7 \mathrm{~nm}$ as compared to control (139.6 nm). The FTIR and UV-Vis spectra of treated sample did not show any change with respect to control. Besides, thermal analysis data showed $42 \%$ decrease in latent heat of fusion. The onset temperature of volatilization and temperature at which maximum volatilization happened was also decreased by $16 \%$ and $12.86 \%$, respectively. The significant decrease in crystallite size may help to improve the spreadability and hence bioavailability of resorcinol in topical formulations. Also increase in volatilization temperature might increase the rate of reaction of resorcinol when used as intermediate. Hence, biofield treatment may alter the physical and thermal properties of resorcinol and make it more suitable for use in pharmaceutical industry.
\end{abstract}

Keywords: Resorcinol; Biofield energy treatment; X-Ray diffraction; Fourier transform infrared spectroscopy; Ultraviolet-Visible spectroscopy; Differential scanning calorimetry; Thermogravimetric analysis

\section{Abbreviations}

XRD: X-Ray Diffraction; FT-IR: Fourier Transform Infrared; DSC: Differential Scanning Calorimetry; TGA: Thermogravimetric Analysis; DTG: Derivative Thermogravimetry; NCCAM: National Centre for Complementary and Alternative Medicine

\section{Introduction}

Resorcinol is a dihydric phenol having the hydroxyl group at 1 and 3 positions in the benzene ring [1]. It occurs naturally in argan oil as main natural phenol. It is white crystalline powder having a faint odour and bitter-sweet taste [2]. It is used as a chemical intermediate in manufacturing of pharmaceuticals, dyestuffs and fungicides such as $p$-aminosalicylic acid, hexylresorcinol and light screening agents for protecting plastics from UV lights [3,4]. It is used in the formulation of several pharmaceuticals such as acne creams, hair dyes, anti-dandruff shampoos, and sun tan lotions. It also possesses various therapeutic uses such as topical antipruritic and antiseptic. It is used to treat seborrheic dermatitis, psoriasis, corns, warts and eczema. It is effective in the treatment of several dermatological problems due to its antibacterial, antifungal and keratolytic effects [5,6]. Resorcinol solution in ethyl alcohol (Jessner's solution) is used in chemical peeling [7], and it has special medical use as biological glue (gelatin-resorcinol-formaldehyde glue) in cardiovascular surgery $[8,9]$. Despite its wide pharmaceutical applications, some side effects are also associated with it, for instance, mild skin irritation, skin redness, etc. It is also hygroscopic i.e., absorb moisture from the air and turns pink on exposure to air or light [10]. By conceiving the usefulness of resorcinol, the present study was attempted to investigate an alternative way that can improve the physical and thermal properties of resorcinol. In recent years, biofield treatment was proved to be an alternative method that has an impact on various properties of living organisms and non-living materials in a cost effective manner. It is already demonstrated that energy can neither be created nor be destroyed, but it can be transferred through various processes such as thermal, chemical, kinetic, nuclear, etc. [11-13]. Similarly, electrical current exists inside the human body in the form of vibratory energy particles like ions, protons, and electrons and they generate a magnetic field in the human body [14,15]. This electromagnetic field of the human body is known as biofield, and energy associated with this field is known as biofield energy [16,17]. The human beings are infused with this precise form of energy, and it provides regulatory and communications functions within the organism $[18,19]$. The health of living organisms can be affected by balancing this energy from the environment through natural exchange process [20]. National Centre for Complementary and Alternative Medicine (NCCAM), which is part of the National Institute of Health (NIH) places biofield therapy (putative energy fields) as subcategory of energy medicine among complementary and alternative medicines. The healing therapy is also considered under this category $[21,22]$. Thus, the human has the ability to harness the energy from environment or universe and can transmit it to any living or non-living object. This process is termed as biofield treatment. Mr. Trivedi's unique biofield treatment (The Trivedi Effect') is well known and significantly studied in different fields such as microbiology [23-25], agriculture [26-28], and biotechnology [29,30]. Recently, it was reported that biofield treatment has changed the atomic, crystalline and powder characteristics as well as spectroscopic

*Corresponding author: Snehasis Jana, Trivedi Science Research Laboratory Pvt. Ltd., Hall-A, Chinar Mega Mall, Chinar Fortune City, Hoshangabad Rd., Bhopal-462026, Madhya Pradesh, India, Tel: +917446660006; E-mail: publication@trivedisrl.com

Received: August 18, 2015; Accepted: August 25, 2015; Published: September 01,2015

Citation: Trivedi MK, Branton A, Trivedi D, Nayak G, Singh R, et al. (2015) Characterisation of Physical, Spectral and Thermal Properties of Biofield treated Resorcinol. Organic Chem Curr Res 4:146. doi:10.4172/2161-0401.1000146

Copyright: @ 2015 Trivedi MK, et al. This is an open-access article distributed under the terms of the Creative Commons Attribution License, which permits unrestricted use, distribution, and reproduction in any medium, provided the original author and source are credited. 
characters of different materials. Moreover, alteration in physical, thermal and chemical properties were also reported in materials like antimony, bismuth and ceramic oxide $[31,32]$. Hence, based on above results the current study was designed to determine the impact of biofield treatment on physical, spectral and thermal properties of resorcinol.

\section{Materials and Methods}

\section{Study design}

Resorcinol was procured from Loba Chemie Pvt. Ltd., India. The sample was divided into two parts and referred as control and treatment. The treatment sample in sealed pack was handed over to $\mathrm{Mr}$. Trivedi for biofield treatment under standard laboratory conditions. Mr. Trivedi provided the treatment through his energy transmission process to the treatment group without touching the sample. The biofield treated sample was returned in the same sealed condition for further characterization using XRD, FT-IR, UV-Vis, DSC, and TGA techniques. For determination of FT-IR and UV-Vis spectroscopic characters, the treated sample was divided into two groups i.e., T1 and T2. Both treated groups were analysed for their spectral characteristics using FT-IR and UV-Vis spectroscopy as compared to control resorcinol sample.

\section{X-ray diffraction (XRD) study}

XRD analysis was carried out on Phillips, Holland PW 1710 X-ray diffractometer system. The X-ray generator was equipped with a copper anode with nickel filter operating at $35 \mathrm{kV}$ and $20 \mathrm{~mA}$. The wavelength of radiation used by the XRD system was $1.54056 \AA$. The XRD spectra were acquired over the $2 \theta$ range of $10^{\circ}-99.99^{\circ}$ at $0.02^{\circ}$ interval with a measurement time of 0.5 second per $2 \theta$ intervals. The data obtained were in the form of a chart of $2 \theta v s$. intensity and a detailed table containing peak intensity counts, $d$ value $(\AA)$, peak width $\left(\theta^{\circ}\right)$, and relative intensity (\%).

The average size of crystallite $(\mathrm{G})$ was calculated from the Scherrer equation [33] with the method based on the width of the diffraction patterns obtained in the X-ray reflected crystalline region.

\section{$\mathrm{G}=\mathrm{k} \lambda /(\mathrm{b} \operatorname{Cos} \theta)$}

Where, $\mathrm{k}$ is the equipment constant (0.94), $\lambda$ is the $\mathrm{X}$-ray wavelength $(0.154 \mathrm{~nm}), B$ in radians is the full-width at half of the peaks and $\theta$ the corresponding Bragg angle.

Percent change in crystallite size was calculated using the following equation:

\section{Percent change in crystallite size $=\left[\left(G_{t}-G_{c}\right) / G_{c}\right] \times 100$}

Where, $G_{c}$ and $G_{t}$ are crystallite size of control and treated powder samples, respectively [34].

\section{Fourier transform-infrared (FT-IR) spectroscopic characterization}

The powdered sample was mixed in spectroscopic grade $\mathrm{KBr}$ in an agate mortar and pressed into pellets with a hydraulic press. FTIR spectra were recorded on Shimadzu's Fourier transform infrared spectrometer (Japan). FT-IR spectra are generated by the absorption of electromagnetic radiation in the frequency range $4000-400 \mathrm{~cm}^{-1}$. The FT-IR spectroscopic analysis of resorcinol (control, T1 and T2) was carried out to evaluate the impact of biofield treatment at atomic and molecular level like bond strength, stability, rigidity of structure etc. [35].

\section{UV-Visible spectroscopic analysis}

The UV-Vis spectral analysis was measured using Shimadzu UV-2400 PC series spectrophotometer. It involves the absorption of electromagnetic radiation from $200-400 \mathrm{~nm}$ range and subsequent excitation of electrons to higher energy states. It is equipped with $1 \mathrm{~cm}$ quartz cell and a slit width of $2.0 \mathrm{~nm}$. The UV-Vis spectra of resorcinol were recorded in methanol solution at ambient temperature. This analysis was performed to evaluate the effect of biofield treatment on the structural property of resorcinol sample. The UV-Vis spectroscopy gives the preliminary information related to the skeleton of chemical structure and possible arrangement of functional groups. With UVVis spectroscopy, it is possible to investigate electron transfers between orbitals or bands of atoms, ions and molecules existing in the gaseous, liquid and solid phase [35].

\section{Differential scanning calorimetry (DSC) study}

Differential scanning calorimeter (DSC) of Perkin Elmer/Pyris-1 was used to study the melting temperature and latent heat of fusion $(\Delta \mathrm{H})$. The DSC curves were recorded under air atmosphere $(5 \mathrm{~mL} /$ min) and a heating rate of $10^{\circ} \mathrm{C} / \mathrm{min}$ in the temperature range of $50^{\circ} \mathrm{C}$ to $350^{\circ} \mathrm{C}$. An empty pan sealed with cover pan was used as a reference sample. Melting temperature and latent heat of fusion were obtained from the DSC curve.

Percent change in latent heat of fusion was calculated [36] using following equations to observe the difference in thermal properties of treated resorcinol sample as compared to control:

$\%$ change in latent heat of fusion $=\frac{\left[\Delta \mathrm{H}_{\text {Treated }}-\Delta \mathrm{H}_{\text {Control }}\right]}{\Delta \mathrm{H}_{\text {Control }}} \times 100$

Where, $\Delta \mathrm{H}_{\text {Control }}$ and $\Delta \mathrm{H}_{\text {Treated }}$ are the latent heat of fusion of control and treated samples, respectively.

\section{Thermogravimetric analysis/Derivative thermogravimetry (TGA/DTG)}

Thermal stability of control and treated samples of resorcinol was analysed by using Mettler Toledo simultaneous Thermogravimetric analyser (TGA/DTG). The samples were heated from room temperature to $400^{\circ} \mathrm{C}$ with a heating rate of $5^{\circ} \mathrm{C} / \mathrm{min}$ under air atmosphere. From TGA curve, onset temperature $\mathrm{T}_{\text {onset }}$ (temperature at which sample start losing weight) and from DTG curve, $\mathrm{T}_{\max }$ (temperature at which sample lost its maximum weight) were observed [37].

Percent change in $\mathrm{T}_{\max }$ was calculated using following equation:

$$
\% \text { change in } \mathrm{T}_{\max }=\left[\left(\mathrm{T}_{\max , \text { treated }}-\mathrm{T}_{\max , \text { control }}\right) / \mathrm{T}_{\max , \text { control }}\right] \times 100
$$

Where, $\mathrm{T}_{\max \text {, control }}$ and $\mathrm{T}_{\max \text {, treated }}$ are the temperature at which sample lost its maximum weight due to volatilization in control and treated sample, respectively. Similarly, the percent change in onset temperature at which sample start losing weight was also calculated.

\section{Results and Discussion}

\section{$\mathrm{X}$-ray diffraction}

$\mathrm{X}$-ray diffraction analysis was conducted to study the crystalline nature of the control and treated samples of resorcinol. XRD diffractogram of control and treated samples of resorcinol are shown in Figure 1 and results are given in Table 1. The XRD diffractogram of control resorcinol showed intense crystalline peaks at $2 \theta$ equal to $18.04^{\circ}, 18.18^{\circ}, 19.11^{\circ}, 19.68^{\circ}, 19.93^{\circ}$, and $20.08^{\circ}$. The intense peaks indicated the crystalline nature of resorcinol. The XRD diffractogram 
Citation: Trivedi MK, Branton A, Trivedi D, Nayak G, Singh R, et al. (2015) Characterisation of Physical, Spectral and Thermal Properties of Biofield treated Resorcinol. Organic Chem Curr Res 4:146. doi:10.4172/2161-0401.1000146

Page 3 of 7
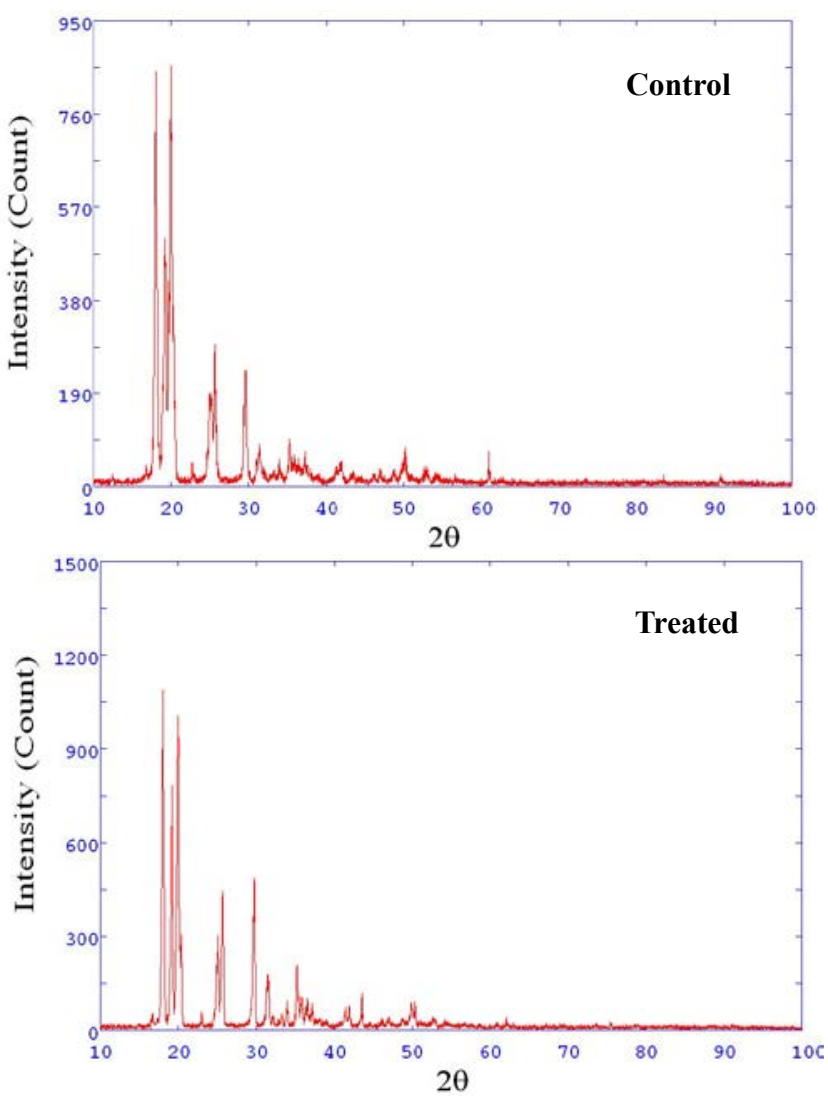

Figure 1: X-ray diffractogram (XRD) of control and treated samples of resorcinol.

\begin{tabular}{|l|l|l|}
\hline Parameter & Control & Treated \\
\hline Volume of unit cell $\times 10^{-23}\left(\mathrm{~cm}^{3}\right)$ & 57.162 & 57.190 \\
\hline Crystallite size $(\mathrm{nm})$ & 139.60 & 104.70 \\
\hline
\end{tabular}

Table 1: XRD analysis of control and treated samples of resorcinol.

of treated resorcinol showed the crystalline peaks at $2 \theta$ equal to $18.04^{\circ}$, $18.18^{\circ}, 19.19^{\circ}, 20.04^{\circ}$ and $29.73^{\circ}$. The peaks in treated sample showed high intensity as compared to control that indicated that crystallinity of treated resorcinol sample increased along the corresponding plane as compared to the control. It is presumed that biofield energy may be absorbed by the treated resorcinol molecules that may lead to form a symmetrical crystalline long range pattern that further results in increasing the symmetry of resorcinol molecules. Besides, the crystallite size was found to be $139.6 \mathrm{~nm}$ in control sample whereas, it was reduced to $104.7 \mathrm{~nm}$ in treated resorcinol. The crystallite size was reduced by $25 \%$ in treated resorcinol as compared to control. Other parameters like the volume of unit cell and molecular weight showed very slight change $(0.05 \%)$ as compared to control sample. The effect of biofield treatment on crystallite size was also reported previously $[37,38]$. It is hypothesized that biofield treatment might produce the energy that causes the fracturing of grains into subgrains hence; the crystallite size was decreased in treated sample as compared to control. As resorcinol is used in many topical formulations, the decrease in crystallite size may improve its spreadability over the skin that further affects its bioavailability [39]. Hence, the treated resorcinol with decreased crystallite size may improve its bioavailability when used in topical formulations.
Spectroscopic studies

\section{FT-IR analysis}

The FT-IR spectra of control and treated (T1 and T2) samples are shown in Figure 2. The spectra showed characteristic vibrational frequencies as follows:

Carbon-Hydrogen vibrations: The aromatic structure of resorcinol showed the presence of $\mathrm{C}-\mathrm{H}$ stretching vibrations in the region $3100-3000 \mathrm{~cm}^{-1}$ which was the characteristic region. The frequency of $\mathrm{C}-\mathrm{H}$ stretching was overlapped with $\mathrm{O}-\mathrm{H}$ stretching frequencies in all three samples, i.e., control, T1 and T2. The $\mathrm{C}-\mathrm{H}$ in-plane bending vibrations were observed at $1379 \mathrm{~cm}^{-1}$ in control and $\mathrm{T} 1$ sample whereas, at $1381 \mathrm{~cm}^{-1}$ in $\mathrm{T} 2$ sample. The $\mathrm{C}-\mathrm{H}$ outof-plane bending vibrations appeared at $773 \mathrm{~cm}^{-1}$ in control and $\mathrm{T} 1$ sample whereas, at $777 \mathrm{~cm}^{-1}$ in T2 sample.

Oxygen-Hydrogen vibrations: In the present study, the $\mathrm{O}-\mathrm{H}$ stretching vibration was observed at $3257-3207 \mathrm{~cm}^{-1}$ in control sample whereas at $3263-3200 \mathrm{~cm}^{-1}$ in T1 and $3281-3072 \mathrm{~cm}^{-1}$ in T2 sample. Generally the O-H band were appeared at frequency range 3600-3300 $\mathrm{cm}^{-1}$; however, broadening of the peak may occur in the presence of $\mathrm{H}$-bonded $\mathrm{O}-\mathrm{H}$ stretching. Hydrogen bonding may shift the peaks to lower frequencies as it was seen in FT-IR spectra of control and treated
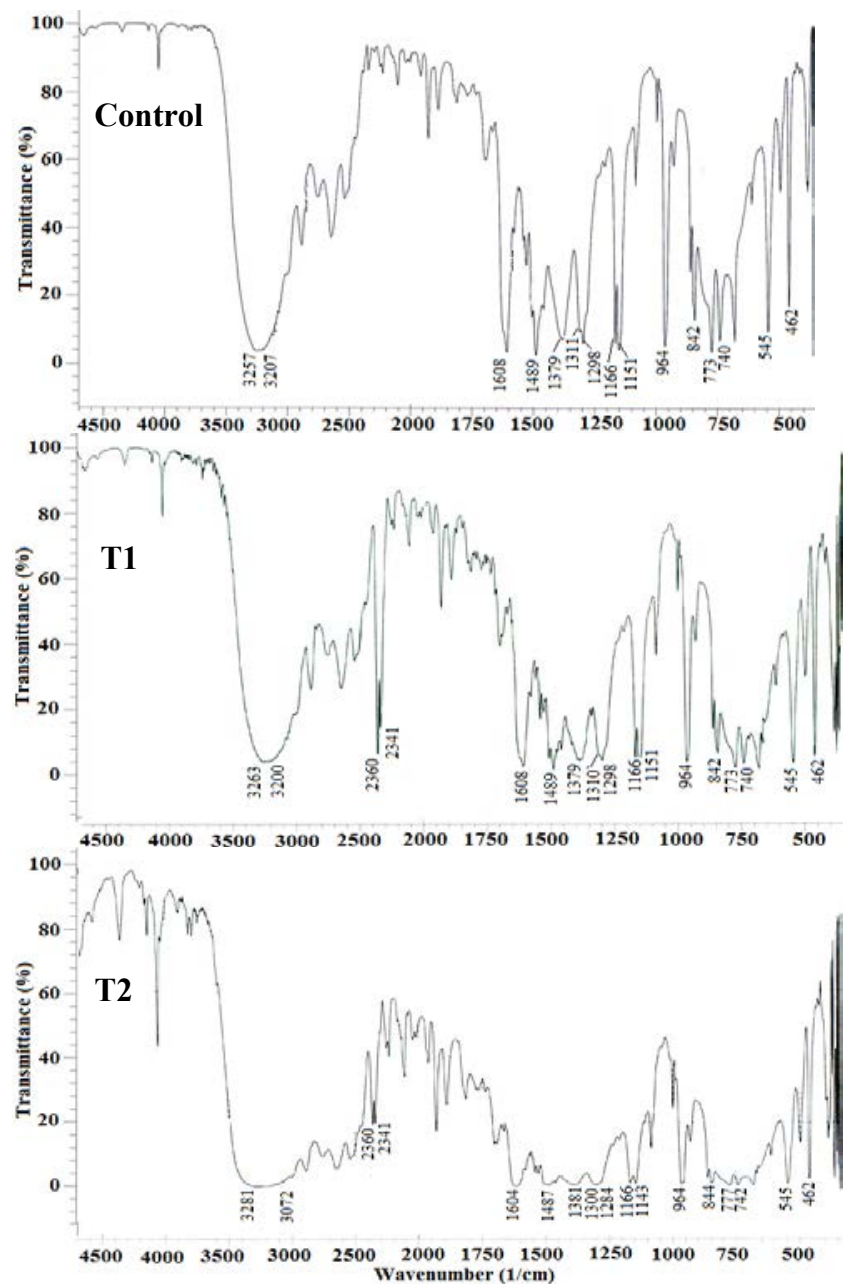

Figure 2: FT-IR spectra of control and treated ( $\mathrm{T} 1$ and $\mathrm{T} 2)$ samples of resorcinol. 
Citation: Trivedi MK, Branton A, Trivedi D, Nayak G, Singh R, et al. (2015) Characterisation of Physical, Spectral and Thermal Properties of Biofield treated Resorcinol. Organic Chem Curr Res 4:146. doi:10.4172/2161-0401.1000146

Page 4 of 7

samples of resorcinol. Hence, it confirmed the presence of H-bonding on resorcinol sample.

\section{C-OH group vibration}

The most important peaks due to $\mathrm{C}-\mathrm{OH}$ stretching mode were appeared at $1311-1298 \mathrm{~cm}^{-1}$ and $1166-1151 \mathrm{~cm}^{-1}$ as doublet peak in the control sample. In T1 sample, the peaks were appeared at 1310$1298 \mathrm{~cm}^{-1}$ and $1166-1151 \mathrm{~cm}^{-1}$ whereas; in T2 sample the peaks were appeared at $1300-1284 \mathrm{~cm}^{-1}$ and $1166-1143 \mathrm{~cm}^{-1}$. The C-OH bending peak was appeared at $462 \mathrm{~cm}^{-1}$ in all three samples i.e., control, T1, and T2.

\section{Ring vibration}

The fundamental vibrational modes of $\mathrm{C}-\mathrm{C}$ stretching generally occurred in the region of $1600-1400 \mathrm{~cm}^{-1}$. In the present study, the peaks observed at 1608 and $1489 \mathrm{~cm}^{-1}$ in control and T1 sample were assigned to $\mathrm{C}-\mathrm{C}$ stretching vibrations. Whereas, in T2, these peaks were appeared at 1604 and $1487 \mathrm{~cm}^{-1}$. Another peak due to ring vibration was appeared at $545 \mathrm{~cm}^{-1}$ in all three samples, i.e., control, T1, and T2. The other important peaks were appeared at 842 and $740 \mathrm{~cm}^{-1}$ due to meta di-substituted ring in control and $\mathrm{T} 1$ sample. Whereas, the same peaks were appeared at 844 and $742 \mathrm{~cm}^{-1}$ in T2 sample. The overall analysis was supported by literature data [4] and showed that there was no significant difference between observed frequencies of control and treated (T1 and T2) samples. Hence, it showed that biofield treatment might not induce any significant change at bonding level.

\section{UV-Vis spectroscopic analysis}

The UV spectra of control and treated samples (T1 and T2) of resorcinol are shown in Figure 3. The UV spectrum of control sample showed absorption peaks at $\lambda_{\max }$ equal to 205,275 and $281 \mathrm{~nm}$ and was well supported by literature [40]. The absorbance peaks were appeared at the same wavelength in treated samples. In T1 sample, the peaks were found at $\lambda_{\max }$ equal to 204, 275 and $281 \mathrm{~nm}$ and in T2 sample, they were appeared at $\lambda_{\max }$ equal to 205,275 and $281 \mathrm{~nm}$. It showed that no change was found in UV spectroscopic properties, i.e., related to structure skeleton, functional groups or energy for electron transfers between orbitals or bands of atoms of treated resorcinol as compared to control.

\section{Thermal studies}

DSC analysis: DSC was used to determine the latent heat of fusion $(\Delta \mathrm{H})$ and melting temperature in control and treated samples of resorcinol. The DSC analysis results of control and treated samples of resorcinol are presented in Table 2. In a solid, the amount of energy required to change the phase from solid to liquid is known as the latent heat of fusion. The result showed that $\Delta \mathrm{H}$ was decreased from 179.77 $\mathrm{J} / \mathrm{g}$ (control) to $103.47 \mathrm{~J} / \mathrm{g}$ in treated resorcinol. It indicated that $\Delta \mathrm{H}$ was decreased by $42.45 \%$ in treated sample as compared to control. It was previously reported that resorcinol molecules possess rigid structure but as the temperature increases, this rigidity breaks down. The molecules rearrange into a hydrocarbon resembling structure and achieve lower van der walls interactions [41]. Hence, it is hypothesized that biofield treatment might produce the energy. This energy probably causes deformation of hydroxyl bond in treated resorcinol, and it needs less energy in the form of $\Delta \mathrm{H}$ to undergo the process of melting. Previously, our group reported that biofield treatment has altered $\Delta \mathrm{H}$ in lead and tin powder [42]. Moreover, the melting temperature of treated $\left(112.56^{\circ} \mathrm{C}\right)$ sample showed very slight change with respect to control $\left(111.18^{\circ} \mathrm{C}\right)$ resorcinol sample.

TGA/DTG analysis: TGA/DTG of control and biofield treated samples are summarized in Table 2. TGA thermogram (Figure 4) showed that control resorcinol sample started losing weight around $200^{\circ} \mathrm{C}$ (onset) and stopped around $246^{\circ} \mathrm{C}$ (end set) which could be due to volatilization of resorcinol [43]. However, the treated resorcinol started losing weight around $168^{\circ} \mathrm{C}$ (onset) and terminated around $215^{\circ} \mathrm{C}$ (end set). It indicated that onset temperature of treated resorcinol was decreased by $16 \%$ as compared to control. Besides, DTG
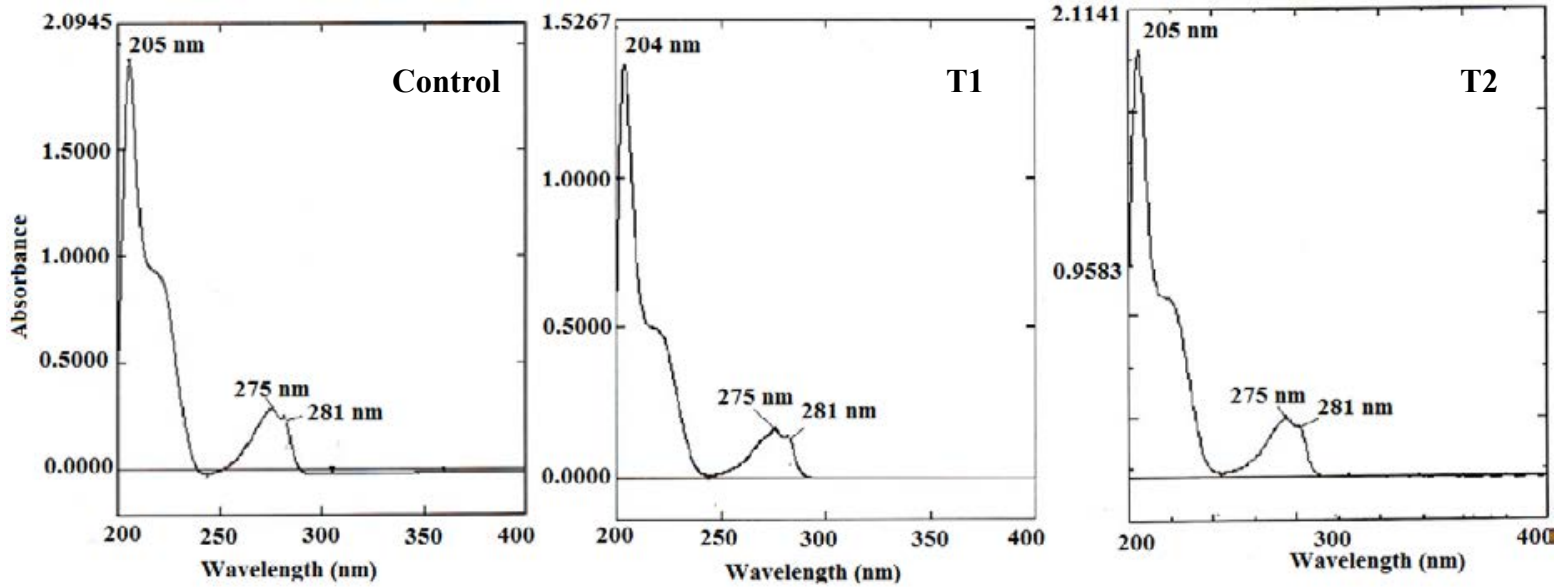

Figure 3: UV-Vis spectra of control and treated (T1 and T2) samples of resorcinol.

\begin{tabular}{|c|c|c|}
\hline Parameter & Control & Treated \\
\hline Latent heat of fusion $\Delta \mathrm{H}(\mathrm{J} / \mathrm{g})$ & 179.77 & 103.47 \\
\hline Melting point $\left({ }^{\circ} \mathrm{C}\right)$ & 111.18 & 112.56 \\
\hline Onset temperature $\left({ }^{\circ} \mathrm{C}\right)$ & 200 & 168 \\
\hline $\mathrm{T}_{\max }\left({ }^{\circ} \mathrm{C}\right)$ & 217.11 & 189.2 \\
\hline
\end{tabular}

Table 2: Thermal analysis of control and treated samples of resorcinol. $T_{\max }:$ Temperature at which maximum weight loss occur. 
Citation: Trivedi MK, Branton A, Trivedi D, Nayak G, Singh R, et al. (2015) Characterisation of Physical, Spectral and Thermal Properties of Biofield treated Resorcinol. Organic Chem Curr Res 4:146. doi:10.4172/2161-0401.1000146
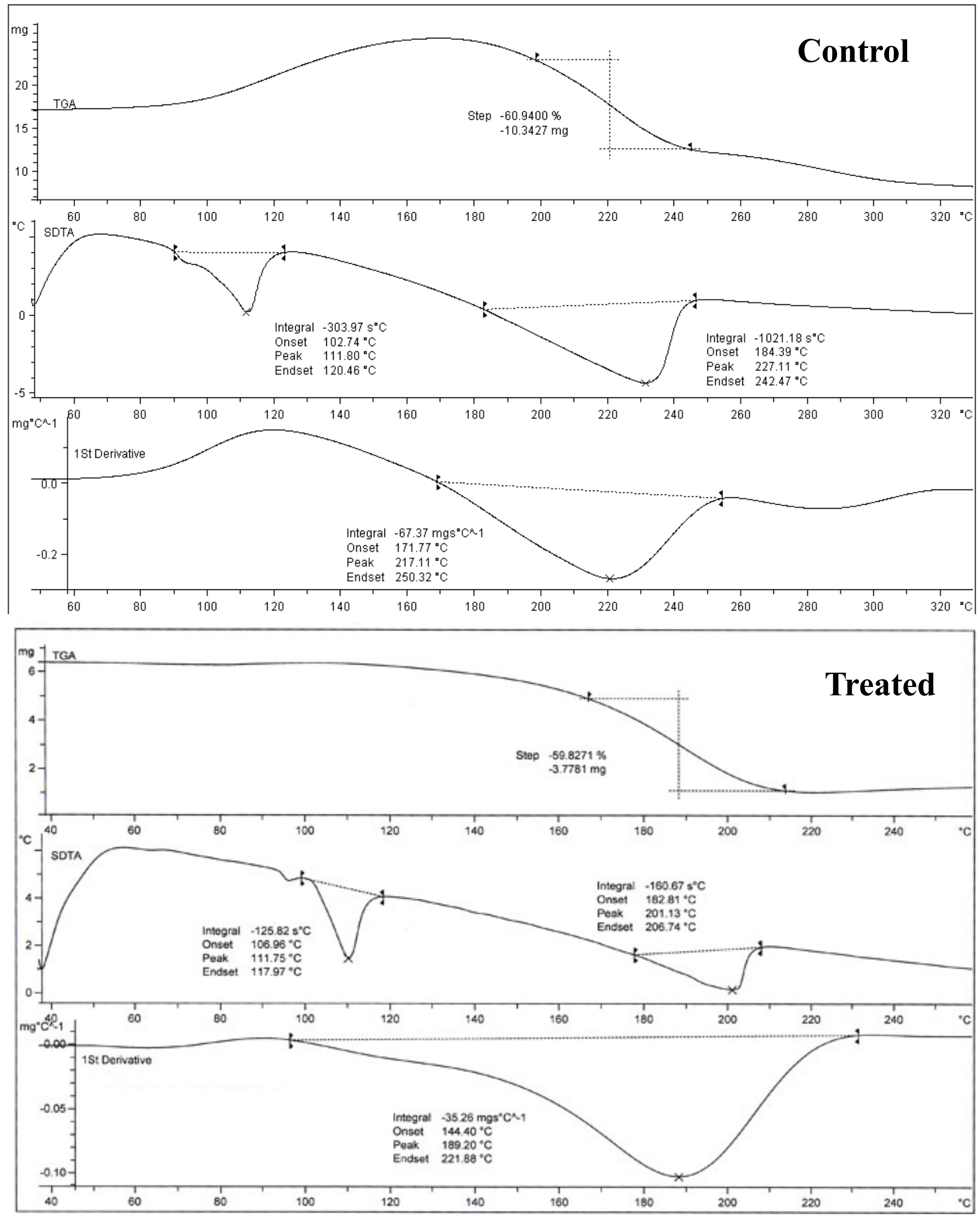

Figure 4: TGA/DTG thermogram of control and treated samples of resorcinol. 
Citation: Trivedi MK, Branton A, Trivedi D, Nayak G, Singh R, et al. (2015) Characterisation of Physical, Spectral and Thermal Properties of Biofield treated Resorcinol. Organic Chem Curr Res 4:146. doi:10.4172/2161-0401.1000146

Page 6 of 7

thermogram data showed that $\mathrm{T}_{\max }$ in control sample was $217.11^{\circ} \mathrm{C}$ and in treated sample, it was found at $189.2^{\circ} \mathrm{C}$. It showed that $\mathrm{T}_{\text {max }}$ was decreased by $12.86 \%$ in treated sample as compared to control. Furthermore, the reduction in onset temperature and $\mathrm{T}_{\max }$ in treated resorcinol with respect to control sample may be correlated with the increase in volatilization of treated resorcinol after biofield treatment. A possible reason for this reduction is that biofield energy might cause some alteration in internal energy which probably resulted into earlier volatilization of treated resorcinol sample as compared to control. Also, decrease in volatilization temperature indicated that resorcinol molecules change their phase from liquid to gas at low temperature, which may results in fasten the rate of those reactions where resorcinol can be used as an intermediate in synthesis [44]. Hence, overall observations suggest that biofield treated resorcinol can be used to enhance the reaction kinetics and yield of the end product.

\section{Conclusion}

The XRD results showed the decrease in crystallite size (25\%) in treated sample as compared to the control that may occur due to biofield treatment that probably produces the energy which leads to fracturing of grains into subgrains. The reduced crystallite size of treated resorcinol sample may be used to improve its bioavailability in topical preparations. The DSC analysis of treated sample showed $42.45 \%$ decrease in $\Delta \mathrm{H}$ value as compared to control, which probably occurred due to deformation of hydroxyl bond in treated sample. The biofield treatment might affect the structure rigidity of resorcinol and hence reduced the latent heat of fusion. TGA/DTG analysis revealed that onset temperature of volatilization and $\mathrm{T}_{\max }$ were decreased by $16 \%$ and $12.86 \%$, respectively. This reduction in volatilization temperature of treated sample might be helpful for resorcinol to be used as a chemical intermediate in the synthesis of various pharmaceuticals. Hence, above study concluded that biofield treatment might alter the physical and thermal properties of resorcinol that could make it more useful in pharmaceutical industries by increasing the bioavailability and reaction kinetics.

\section{Acknowledgements}

The authors would like to acknowledge the whole team of Sophisticated Analytical Instrument Facility (SAIF), Nagpur and MGV Pharmacy College, Nashik for providing the instrumental facility. We are very grateful to Trivedi Science, Trivedi Master Wellness and Trivedi Testimonials for their support in this research work.

\section{References}

1. Durairaj RB (2005) Resorcinol: Chemistry, technology and applications. Springer-Verlag, Berlin, Germany.

2. Charrouf Z, Guillaume D (2007) Phenols and polyphenols from Argania spinosa. Am J Food Technol 2: 679-683.

3. Schmiedel KW, Decker D (2000) Resorcinol. Ullmann's encyclopedia of industrial chemistry. Wiley-VCH, Weinheim.

4. Dressler H (1994) Resorcinol, its uses and derivatives. Springer, NewYork, USA.

5. Hahn S (2006) Resorcinol. Concise international chemical assessment document. WHO Press, Geneva, Switzerland.

6. Karam PG (1993) 50\% resorcinol peel. Int J Dermatol 32: 569-574.

7. Hernandez-Perez E, Jaurez-Arce V (2000) Gross and microscopic findings with a combination of Jessner solution plus $53 \%$ resorcinol paste in chemical peels. J Cosmet Surg 17: 85-89.

8. Bachet J, Guilmet D (1999) The use of biological glue in aortic surgery. Cardiol Clin 17: 779-796

9. Kazui T, Washiyama N, Bashar AH, Terada H, Suzuki K, et al. (2001) Role of biologic glue repair of proximal aortic dissection in the development of early and midterm redissection of the aortic root. Ann Thorac Surg 72: 509-514.
10. Gile TJ (2004) Safety never takes a holiday. Clin Leadersh Manag Rev 18 342-348.

11. Becker RO, Selden G (1985) The body electric: Electromagnetism and the foundation of life, New York City, William Morrow and Company.

12. Barnes RB (1963) Thermography of the human body. Science 140: $870-877$

13. Born M (1971) The Born-Einstein Letters. (1st edn), Walker and Company, New York.

14. Prakash S, Chowdhury AR, Gupta A (2015) Monitoring the human health by measuring the biofield "aura": An overview. IJAER 10: 27637-27641.

15. Einstein A (1905) Does the inertia of a body depend upon its energy-content? Ann Phys 18: 639-641.

16. Rivera-Ruiz M, Cajavilca C, Varon J (2008) Einthoven's string galvanometer: the first electrocardiograph. Tex Heart Inst J 35: 174-178.

17. Rubik B (2002) The biofield hypothesis: its biophysical basis and role in medicine. J Altern Complement Med 8: 703-717.

18. Garland SN, Valentine D, Desai K, Langer C, Evans T, et al. (2013) Complementary and alternative medicine use and benefit finding among cancer patients. J Altern Complement Med 19: 876-881.

19. Peck SD (1998) The efficacy of therapeutic touch for improving functional ability in elders with degenerative arthritis. Nurs Sci Q 11: 123-132.

20. Saad M, Medeiros RD (2012) Distant healing by the supposed vital energyScientific bases. Complementary Therapies for the Contemporary Healthcare. U.S.

21. Thomas AH (2012) Hidden in plain sight: The simple link between relativity and quantum mechanics. Swansea, UK

22. $\mathrm{NIH}$, National Center for Complementary and Alternative Medicine. CAM Basics. Publication 347. [October 2, 2008]. Available at: http://nccam.nih.gov/ health/whatiscam/

23. Trivedi MK, Patil S, Shettigar H, Gangwar M, Jana S (2015) An effect of biofield treatment on multidrug-resistant Burkholderia cepacia: A multihost pathogen. J Trop Dis 3: 167

24. Trivedi MK, Patil S, Shettigar H, Gangwar M, Jana S (2015) Antimicrobial sensitivity pattern of Pseudomonas fluorescens after biofield treatment. $\mathrm{J}$ Infect Dis Ther 3: 222

25. Trivedi MK, Patil S, Shettigar H, Bairwa K, Jana S, et al. (2015) Phenotypic and biotypic characterization of Klebsiella oxytoca: An impact of biofield treatment. J Microb Biochem Technol 7: 203-206.

26. Shinde V, Sances F, Patil S, Spence A (2012) Impact of biofield treatment on growth and yield of lettuce and tomato. Aust J Basic Appl Sci 6: 100-105.

27. Sances F, Flora E, Patil S, Spence A, Shinde V, et al. (2013) Impact of biofield treatment on ginseng and organic blueberry yield. Agrivita J Agric Sci 35: 22-29.

28. Lenssen AW (2013) Biofield and fungicide seed treatment influences on soybean productivity, seed quality and weed community. Agricultural Journal 8: $138-143$.

29. Nayak G, Altekar N (2015) Effect of biofield treatment on plant growth and adaptation. J Environ Health Sci 1: 1-9.

30. Patil SA, Nayak GB, Barve SS, Tembe RP, Khan RR, et al. (2012) Impact of biofield treatment on growth and anatomical characteristics of Pogostemon cablin (Benth.). Biotechnology 11: 154-162.

31. Dabhade VV, Tallapragada RR, Trivedi MK (2009) Effect of external energy on atomic, crystalline and powder characteristics of antimony and bismuth powders. Bull Mater Sci 32: 471-479.

32. Trivedi MK, Nayak G, Patil S, Tallapragada RM, Latiyal O, et al. (2015) Studies of the atomic and crystalline characteristics of ceramic oxide nano powders after bio field treatment. Ind Eng Manage 4: 161

33. Alexander L, Klug HP (1950) Determination of crystallite size with the x-ray spectrometer. J Appl Phys 21: 137-142.

34. http://shodhganga.inflibnet.ac.in:8080/jspui/bitstream/10603/7080/16/16_ chapter\%207.pdf

35. Pavia DL, Lampman GM, Kriz GS (2001) Introduction to spectroscopy. (3rd edn), Thomson Learning, Singapore. 
Citation: Trivedi MK, Branton A, Trivedi D, Nayak G, Singh R, et al. (2015) Characterisation of Physical, Spectral and Thermal Properties of Biofield treated Resorcinol. Organic Chem Curr Res 4:146. doi:10.4172/2161-0401.1000146

36. http://academic.brooklyn.cuny.edu/physics/sobel/CoreExpts/CalorLatent.html

37. Trivedi MK, Patil S, Tallapragada RM (2015) Effect of biofield treatment on the physical and thermal characteristics of aluminium powders. Ind Eng Manage 4: 151.

38. Trivedi MK, Patil S, Tallapragada RM (2012) Thought intervention through bio field changing metal powder characteristics experiments on powder characteristics at a PM plant. Future Control and Automation LNEE 173: 247252

39. Niazi SK (2009) Handbook of Pharmaceutical Manufacturing Formulations: Semisolid Products. (2nd edn), CRC Press.
40. Lide DR, Milne GWA (1994) Handbook of Data on Organic Compounds. (3rd edn), CRC Press, USA

41. Robertson JM, Ubbelohde AR (1938) A new form of resorcinol II. Thermodynamic properties in relation to structure. Proc Royal Soc London Ser A 167: 136-147.

42. Trivedi MK, Patil S, Tallapragada RM (2013) Effect of biofield treatment on the physical and thermal characteristics of silicon, tin and lead powders. J Materia Sci Eng 2: 125.

43. O'Neil MJ (2013) The Merck Index - An encyclopedia of chemicals, drugs, and biologicals. Royal Society of Chemistry, Cambridge, UK.

44. Espenson JH (1995) Chemical kinetics and reaction mechanisms. (2nd edn), Mcgraw-Hill, U.S.
Citation: Trivedi MK, Branton A, Trivedi D, Nayak G, Singh R, et al. (2015) Characterisation of Physical, Spectral and Thermal Properties of Biofield treated Resorcinol. Organic Chem Curr Res 4:146. doi:10.4172/2161-0401.1000146

\section{OMICS International: Publication Benefits \& Features}

\section{Unique features:}

Increased global visibility of articles through worldwide distribution and indexing

- Showcasing recent research output in a timely and updated manner

Special issues on the current trends of scientific research

Special features:

700 Open Access Journals

50,000 Editorial team

Rapid review process

Quality and quick editorial, review and publication processing

Indexing at PubMed (partial), Scopus, EBSCO, Index Copernicus, Google Scholar etc.

Sharing Option: Social Networking Enabled

- Authors, Reviewers and Editors rewarded with online Scientific Credits

Better discount for your subsequent articles

Submit your manuscript at: http://www.omicsgroup.org/iournals/submission 